\title{
PENGARUH KARAKTERISTIK PERUSAHAAN TERHADAP KEPUTUSAN PENDANAAN (PERBANDINGAN ANTAR SUB SEKTOR INDUSTRI MANUFAKTUR)
}

\author{
Amanda Ayu Widarti \\ Fakultas Ekonomi dan Bisnis Universitas Airlangga \\ e-mail: amanda.ayu33@gmail.com \\ I Made Sudana \\ Fakultas Ekonomi dan Bisnis Universitas Airlangga \\ e-mail: imadesudana@yahoo.co.id
}

\begin{abstract}
The aim of this paper is to determine the difference between the financial decisions and the influence of firm characteristics on the financial decisions of each sub-sector of the manufacturing industry in Indonesia. Data obtained from company financial statements 2009-2011. The analysis technique used ANOVA and multiple regression. Based on the analysis it can be concluded that the total debt to total assets and short-term debt to total assets has a significant difference between the miscellaneous industry, consumer goods and basic industry and chemicals. The result suggest that short-term debt in miscellaneous industry affected by profitability and asset structure, while in the consumer goods is influenced by the size, and for the basic industry and chemicals is affected by profitability, asset structure and growth. Long-term debt in the miscellaneous industry affected by the size and business risk, while consumer goods is affected by profitability, and for the basics industry and chemicals is influenced by size profitability and asset structure. Total debt to total assets of miscellaneous industry is affected by size, profitability, asset structure and business risk, while in the basics industry and chemicals is influenced by size and profitability.
\end{abstract}

Keyword: firm characteristics, financial decisions.

\begin{abstract}
Abstrak
Tujuan penelitian ini adalah untuk menentukan perbedaan antara keputusan keuangan dan pengaruh karakteristik perusahaan pada keputusan keuangan di setiap sub-sektor pada perusahaan manufaktur di Indonesia. Teknik analisis menggunakan ANOVA dan regresi berganda. Berdasarkan hasil analisis dapat disimpulkan bahwa total utang dengan aset dan utang jangka pendek dengan total aset memiliki perbedaan signifikan di antara aneka industri, barang konsumsi dan industri dasar, dan industri kimia. Hasil riset menunjukkan bahwa utang jangka pendek di aneka industri dipengaruhi oleh profitabilitas dan struktur aset, sementara pada industri barang konsumsi dipengaruhi oleh ukuran perusahaan, dan untuk industri dasar dan kimia dipengaruhi oleh profitabilitas, struktur aset, dan pertumbuhan perusahaan. Utang jangka panjang aneka industri dipengaruhi oleh ukuran dan risiko bisnis, sementara pada barang konsumsi dipengaruhi oleh profitabilitas, dan untuk industri dasar dan kimia dipengaruhi oleh ukuran, profitabilitas, dan struktur aset. Total utang dengan aset di aneka industri dipengaruhi oleh ukuran, profitabilitas, struktur aset, dan risiko bisnis, sementara di industri dasar dan kimia dipengaruhi oleh ukuran perusahaan dan profitabilitas.
\end{abstract}

Kata kunci: karakteristik perusahaan, keputusan keuangan

\section{PENDAHULUAN}

Sumber pendanaan perusahaan berasal dari pendanaan internal dan pendanaan eksternal.
Pendanaan internal merupakan sumber pendanaan yang berasal dari dalam perusahaan yang dihasilkan dari laba yang disisihkan 
perusahaan. Sumber pembiayaan eksternal diperoleh perusahaan dengan melakukan pinjaman kepada pihak ketiga atau menjual sahamnya kepada masyarakat (go public) di pasar modal. Sumber pendanaan yang berasal dari internal perusahaan pada umumnya tidak cukup untuk membiayai aktivitas dan pertumbuhan perusahaan. Oleh sebab itu perusahaan, menggunakan sumber pendanaan yang berasal dari eksternal perusahaan berupa utang, walaupun akan berakibat meningkatkan risiko keuangan perusahaan.

Masing-masing perusahaan memiliki keputusan pendanaan yang berbeda. Keputusan pendanaan tersebut dipengaruhi oleh banyak faktor, seperti karakteristik perusahaan atau industry, dan kondisi ekonomi. Masing-masing perusahaan mempunyai karakteristik berbeda karena industrinya yang berbeda, dengan demikian keputusan pendanaan antara perusahaan atau industri satu dengan lain juga berbeda.

Perusahaan yang terdaftar di Bursa Efek Indonesia, dibagi menjadi beberapa sektor. Berdasarkan Jakarta Stock Industrial Classification (Jasica) Index membagi perusahaan-perusahaan tersebut menjadi 9 sektor, Yaitu: Primary sectors terdiri dari sektor agriculture dan sektor pertambangan. Secondary sectors terdiri dari sektor industri dasar dan kimia, sektor aneka industri dan sektor consumer goods property. Tertiary Sectors terdiri dari sektor real estate and building construction, sektor infrastructure, utilities and transportation, sektor keuangan, dan sektor trade, services and investment. Di antara sektor-sektor tersebut secondary sectors atau yang menurut sistematika Indonesia Capital Market Direcory (ICMD) disebut dengan manufaktur, yang terdiri dari sub sektor industri dasar dan kimia, sektor aneka industri dan sektor consumer goods yang akan dijadikan sebagai objek pada penelitian ini.

Rata-rata rasio total utang terhadap total aktiva tahun 2009-2011 pada sub sektor consumer goods $41,36 \%$, sektor aneka industri mempunyai rata-rata $89,46 \%$, sektor industri dasar dan kimia mempunyai rata-rata $54 \%$. Perusahaan yang memiliki relatif lebih banyak utang akan memiliki risiko keuangan yang lebih tinggi dibandingkan perusahaan yang menggunakan sedikit utang. Adanya keberagaman struktur keuangan pada masing- masing sub sektor tersebut, menarik untuk dikaji lebih lanjut, barkaitan dengan faktorfaktor apa saja yang memengaruhi keputusan pendanaan tersebut.

Beberapa penelitian menemukan hasil yang berbeda mengenai pengaruh karakteristik perusahaan terhadap keputusan pendanaan. Abor (2007) dan Bokpin dan Arko (2009) menemukan bahwa profitabilitas, struktur aktiva berpengaruh negatif dan size berpengaruh positif terhadap struktur modal di Ghana. Chen (2004) pada penelitiannya terhadap perusahaan di China menemukan profitabilitas dan size berpengaruh negatif terhadap struktur modal, tetapi growth dan struktur aktiva berpengaruh positif terhadap struktur modal. Penelitian Indrajaya dkk (2011) di Indonesia menemukan bahwa growth, size, struktur aktiva, risiko bisnis berpengaruh positif, sedangkan profitabilitas berpengaruh negatif terhadap struktur modal. Hal ini dapat terjadi karena perbedaan sampel, waktu penelitian, dan populasi yang diteliti.

Penelitian ini hendak mengkaji perbedaan keputusan pendanaan antara masingmasing sub sektor industri manufaktur yang terdaftar di BEI dan pengaruh karakteristik perusahaan terhadap keputusan pendanaan pada masing-masing sub sektor industri manufaktur yang terdaftar di BEI periode 2009 sampai 2011.

\section{LANDASAN TEORI DAN PENGEM- BANGAN HIPOTESIS}

\section{Keputusan Pendanaan}

Keputusan pendanaan adalah keputusan yang menyangkut tentang bentuk dan komposisi pendanaan yang dipergunakan perusahaan (Suad, 1995). Brealey, Myers \& Marcus (2001:446) menyatakan financing decision adalah bentuk dan jumlah dari pendanaan atau pembiayaan dari sebuah investasi perusahaan. Keputusan pendanaan berkaitan dengan proses pemilihan sumber dana yang dipakai untuk membelanjai investasi yang direncanakan dari berbagai alternatif sumber dana yang tersedia, sehingga diperoleh suatu kombinasi pembelanjaan yang paling efisien (Sudana, 2009:5).

Sumber dana perusahaan dibagi menjadi dua, yaitu sumber dana internal yang berasal dari laba yang ditahan hasil kegiatan operasional perusahaan. Sumber dana eksternal 
berasal dari pinjaman atau penerbitan saham perusahaan. Hasil dari keputusan pendanaan akan tercermin pada struktur keuangan. Struktur keuangan tampak pada neraca sebelah kredit, yang terdiri atas utang lancar, utang jangka panjang dan modal.

Perusahaan dihadapkan dua pilihan atas keputusan pendanaan dengan utang, yaitu menggunakan utang jangka pendek atau utang jangka panjang. Secara normatif investasi jangka panjang membutuhkan sumber pendanaan jangka panjang dan investasi jangka pendek membutuhkan sumber pendanaan jangka pendek. Halley and Schall, (1979) menyatakan "many firms have had both short term and long term debt outstanding for a considerable period." Kebutuhan pendanaan perusahaan dapat dipenuhi baik melalui pendanaan jangka panjang maupun jangka pendek. Tugas manajer keuangan berhubungan dengan bagaimana perusahaan mendapatkan dan mengelola dana yang dibutuhkan untuk mendukung investasi yang dilakukan perusahaan, sesuai dengan jangka waktunya.

Hasil keputusan pendanaan yang diambil oleh pihak manajemen tercermin dalam struktur keuangan perusahaan yang diukur dengan cara sebagai berikut:

Total debt to asset ratio (DTA), adalah perbandingan antara total utang dengan total aset yang dimiliki oleh perusahaan.

DTA $=\frac{\text { Total Utang }}{\text { Total Aktiva }}$

Short term debt to asset ratio (SDTA), adalah perbandingan antara total utang jangka pendek dengan total asset yang dimiliki oleh perusahaan.

SDT $A=\frac{\text { Utang Jangka Pendek }}{\text { Total Aktiva }}$

Long term debt to asset ratio (LDTA,) adalah perbandingan antara total utang jangka panjang dengan total asset yang dimiliki perusahaan

LDTA $=\frac{\text { Utang Jangka Panjang }}{\text { Total Aktiva }}$

\section{Karakteristik Perusahaan}

Karakteristik perusahaan merupakan ciri khas atau spesifik perusahaan yang dapat mempengaruhi kinerja perusahaan. Karakteristik perusahaan dapat memengaruhi keputusan pemenuhan sumber dana perusahaan (Ozkan,
2001). Wald (1999), mengemukakan bahwa adanya perbedaan karakteristik perusahaan akan menyebabkan perbedaan pada komposisi struktur keuangan sebuah perusahaan. Karakteristik perusahaan yang diteliti pada penelitian ini meliputi: sizeprofitabilitas, struktur aktiva, growth, dan risiko bisnis.

\section{Ukuran perusahaan (Size)}

Ukuran (sizф perusahaan menunjukkan besar kecilnya ukuran perusahaan pada saat tertentu yang dapat dilihat dari jumlah penjualan, atau jumlah aktiva yang dimiliki perusahaan. Firm size pada penelitian ini diukur menggunakan logaritma natural dari penjualan.

Size $=($ Ln sales $)$

Nilai penjualan memperlihatkan keberhasilan investasi periode masa lalu dan dapat dijadikan prediksi pertumbuhan yang akan datang. Omran dan Pointon (2009), pada penelitian di Mesir dan Buferna (2011) pada penelitiannya di Lybia menemukan bahwa size berpengaruh positif terhadap keputusan pendanaan. Chen (2003) menemukan bahwa size berpengaruh positif pada rasio total utang di China, namun size juga ditemukan berpengaruh negatif pada rasio utang jangka panjang. Mouamer (2011) menemukan di Palestina bahwa size berpengaruh negatif terhadap utang jangka pendek dan total utang. Semakin besar nilai penjualan perusahaan memperlihatkan semakin besar ukuran perusahaan. Pihak kreditor lebih menyukai untuk memerikan pinjaman kepada perusahaan besar daripada perusahaan kecil, karena lebih dipercaya, sehingga perusahaan besar mempunyai peluang yang lebih luas dan mudah untuk mendapatkan pinjaman.

H1: Ukuran perusahaan berpengaruh positif terhadap penggunaan utang.

\section{Profitabilitas}

Profitabilitas menunjukkan kemampuan suatu perusahaan untuk memeroleh keuntungan dengan menggunakan aktiva, modal atau penjualan. Kemampuan perusahaan tersebut merupakan hasil dari berbagai kebijakan dan keputusan yang dilakukan manajemen dalam memanfaatkan berbagai sumber dana atau aktiva yang ada. Keputusan pendanaan yang tidak tepat akan menimbulkan biaya tetap yang tinggi, sehingga profitabilitas perusahaan akan menurun. Para investor dan kreditor sangat 
berkepentingan dalam mengevaluasi kemampuan perusahaan untuk menghasilkan laba saat ini maupun masa datang. Abor (2007) pada penelitiannya di Ghana dan Chen (2003) pada penelitian di China menemukan profitabilitas berpengaruh negatif terhadap keputusan pendanaan dengan utang. Wald (199), menemukan bahwa profitabilitas berpengaruh negatif terhadap penggunaan utang di Negara Jepang, Jerman, Perancis, US dan Inggris. Buferna, et al (2005) menemukan bahwa Profitabilitas berpengaruh positif terhadap total utang dan utang jangka pendek. Brealey, Myers \& Marcus (2001) menjelaskan kebanyakan perusahaan dengan profit besar umumnya meminjam lebih sedikit. Hal tersebut bukan karena perusahaan mempunyai target debt ratio yang rendah, tetapi karena perusahaan tidak memerlukan dana dari luar mengingat sumber dana internal berupa laba ditahan telah mencukupi kebutuhan dana perusahaan. Profitabilitas adalah kemampuan perusahaan untuk menghasilkan laba bersih dengan total aktiva (ROA), yang diukur dengan rumus:

$R O A=\frac{\text { Net Income }}{\text { Total Asset }}$

Perusahaan dengan keuntungan yang lebih sedikit akan lebih banyak menerbitkan utang karena perusahaan tidak mempunyai dana internal yang cukup untuk membiayai investasi dan operasi perusahaan.

$\mathrm{H} 2$ : Profitabilitas berpengaruh negatif terhadap penggunaan utang.

\section{Struktur Aktiva}

Aktiva dapat digolongkan menjadi aktiva lancar dan aktiva tetap. Komposisi kedua aktiva tersebut terhadap total aktiva akan menentukan struktur kekayaan atau lebih dikenal dengan struktur aktiva dari sebuah perusahaan. Struktur aktiva adalah perimbangan atau perbandingan baik dalam artian absolut maupun dalam artian relatif antara aktiva lancar dengan aktiva tetap (Riyanto, 2001). Struktur aktiva merupakan penentuan berapa besar alokasi untuk masingmasing komponen aktiva, baik aktiva lancar maupun aktiva tetap. Struktur aktiva merupakan rasio aktiva tetap dengan total aktiva yang dimiliki perusahaan.

Struktur aktiva $=\frac{\text { Aktiva Tetap }}{\text { Total Aktiva }}$ 6)
Chen (2003) dalam penelitian menemukan struktur aktiva berpengaruh positif terhadap penggunaan utang perusahaan di China. Omran dan Pointon (2009) menemukan struktur aset berpengaruh negatif terhadap total utang dan utang jangka pendek pada perusahaan di Mesir. Buferna, et al (2005) menemukan pengaruh negatif tangibility terhadap long term debt ratio dan total debt ratio untuk perusahaan swasta di Mesir. Struktur aktiva yang tinggi menunjukkan bahwa perusahaan tersebut secara relatif memiliki proporsi aktiva tetap yang lebih besar dibandingkan aktiva lancar. Aktiva tetap perusahaan tesebut dapat dijadikan sebagai jaminan kepada kreditor. Jaminan tersebut menjadi dasar kepercayaan kreditor untuk memerikan lebih banyak pinjaman kepada perusahaan. Perusahaan dengan aktiva tetap yang tinggi cenderung menggunakan utang jangka panjang untuk mendanai kebutuhannya, sedangkan perusahaan dengan aktiva lancar yang lebih tinggi cenderung menggunakan utang jangka pendek untuk mendanai kebutuhan dananya.

H3: Struktur aktiva berpengaruh postif terhadap penggunaan utang.

\section{Pertumbuhan (growth) perusahaan}

Pertumbuhan (growth) perusahaan merupakan pembentuk nilai perusahaan yang tidak bisa dijadikan jaminan utang dan bisa menghasilkan pendapatan di masa yang akan datang. Growth merupakan tingkat pertumbuhan perusahaan yang tergantung pada investasi yang dilakukan perusahaan dan dapat meningkatkan nilai perusahaan. Perusahaan yang mempunyai kesempatan tumbuh atau berkembang adalah perusahaan yang mempunyai kapasitas ekspansi relatif besar, mempunyai kesempatan untuk mengembangkan lini produk baru, mampu dan berkesempatan mengambil alih perusahaan lain atau mampu memelihara dan mengganti aktiva perusahaan. Hal ini berarti perusahaan mempunyai kesempatan memperluas pangsa pasar, sehingga memungkinkan peningkatan penjualan dan peningkatan keuntungan perusahaan. Penelitian yang dilakukan Chen (2003) di China dan Abor (2007) di Ghana, menemukan bahwa growth berpengaruh positif terhadap utang. Eriotis, et al (2007) menemukan bahwa growth mempunyai pengaruh negatif terhadap struktur modal perusahaan di Yunani, hasil yang sama juga ditemukan Buferna (2005) 
pada pengaruh negatif growth terhadap utang di perusahaan Lybia.

Pertumbuhan (growth) perusahaan, diukur dengan pertumbuhan penjualan perusahaan tiap tahun.

$$
\text { Growth }=\frac{\text { Sales }_{\mathrm{t}}-\text { Sales }_{\mathrm{t}-1}}{\text { Sales }_{\mathrm{t}-1}}
$$

Tingkat pertumbuhan penjualan perusahaan saat ini dapat dapakai untuk memprediksi mengenai kondisi penjualan di masa mendatang. Brigham dan Houston (2001), mengatakan bahwa perusahaan dengan pertumbuhan penjualan yang relatif tinggi dapat menggunakan utang lebih banyak dibandingkan dengan perusahaan yang pertumbuhan penjualannya rendah. Apabila penjualan perusahaan mengalami kenaikan, maka kreditor menilai kondisi perusahaan mengalami perkembangan. Hal tersebut menjadi salah satu pertimbangan kreditor untuk memerikan pinjaman kepada perusahaan, karena kondisi perusahaan dinilai aman dan diharapkan akan mampu membayar kewajibannya.

H4: Pertumbuhan perusahaan berpengaruh positif terhadap penggunaan utang.

\section{Risiko bisnis}

Risiko bisnis adalah risiko yang berkaitan dengan keputusan investasi. Beda bidang industri yang menjadi bisnis perusahaan berbeda pula risiko bisnisnya. Risiko bisnis berbeda-beda di antara perusahaan yang satu dengan perusahaan yang lain di industri yang sama, hal ini karena investasi pada aktiva tetap masing-masing perusahaan berbeda-beda. Penggunaan aktiva tetap dalam operasi perusahaan akan menimbulkan beban tetap berupa penyustan yang akan berdampak pada operating laverage, sebagai salah satu proksi untuk mengukur risiko bisnis perusahaan. Perusahan dengan operating leverage yang tinggi cenderung mengurangi penggunaan utangnya, mengingat risiko bisnis yang timbul dari aktivitas operasional perusahaan sudah tinggi, dan apabila perusahaan tidak mengurangi penggunakan utang, maka risiko perusahaan akan bertambah dengan risiko keuangan yang timbul dari penggunaan utang. Wald (1999), menemukan bahwa risiko berpengaruh negatif terhadap utang di Negara Amerika Serikat dan Perancis, sedangkan pengaruh positif risiko bisnis terhadap utang ditemukan di Negara Jepang, Jerman dan Inggris. Huang dan Song, menemukan bahwa di China perusahaan dengan risiko bisnis yang tinggi mempunyai tingkat utang yang tinggi pula, hasil yang sama juga di temukan Omran dan Pointon (2009) pada perusahaan di Mesir.

Riskiko bisnis pada penelitian ini diukur dengan degree of operating leverage (DOL), yaitu besarnya persentase perubahan EBIT akibat dari persentase perubahan pada penjualan tertentu.

DOL $=\frac{\% \Delta \text { EBIT }}{\% \Delta \text { Sales }}$

Semakin besar $D O L$, berarti risiko bisnis perusahaan juga akan semakin besar, karena jika terjadi perubahan penjualan tertentu akan mengakibatkan perubahan EBIT yang lebih besar, dan sebaliknya. Risiko bisnis yang besar akan berdampak pada fluktuasi pendapatan perusahaan, akibatnya perusahaan dengan pendapatan yang tidak stabil akan kesulitan untuk memperoleh pinjaman dana dari pihak kreditor.

H5: Risiko bisnis berpengaruh negatif terhadap penggunaan utang.

\section{METODE PENELITIAN}

\section{Variabel Penelitian}

Variabel dependen, yaitu keputusan pendanaan. Keputusan pendanaan merupakan kebijakan yang diambil perusahaan terkait dengan penggunaan sumber pendanaan eksternal, yaitu utang. Keputusan pendanaan pada penelitian ini diukur dengan cara sebagai berikut: a) Total debt to asset ratio (DTA), adalah perbandingan antara total utang dengan total aset yang dimiliki oleh perusahaan yang diukur dengan rumus nomor 1). b) Short term debt to asset ratio (SDTA), adalah perbandingan antara total utang jangka pendek dengan total asset yang dimiliki oleh perusahaan yang diukur dengan rumus nomor 2). c) Long term debt to asset ratio (LDTA,) adalah perbandingan antara total utang jangka panjang dengan total asset yang dimiliki perusahaan yang diukur dengan rumus nomor 3).

Variabel Independen. a) Ukuran (sizф perusahaan adalah besarnya perusahaan yang diukur dengan rumus nomor 4). b) Profitabilitas adalah kemampuan perusahaan untuk menghasilkan laba bersih dengan total aktiva yang 
diukur dengan rumus nomor 5). c) Struktur aktiva merupakan rasio aktiva tetap dengan total aktiva yang dimiliki perusahaan yang diukur dengan rumus nomor 6). d) Pertumbuhan (growth) perusahaan, merupakan pertumbuhan penjualan perusahaan tiap tahun yang diukur dengan rumus nomor 7). e) Risiko bisnis, adalah sensitivitas perubahan EBIT sebagai akibat perubahan penjualan, yang diproksikan dengan degree of operating leverage (DOL) yang diukur dengan rumus nomor 8)

\section{Model Analisis}

Penelitian ini menggunakan model analisis sebagai berikut: ANOVA untuk mengetahui perbedaan rata-rata keputusan pendanaan antar masing-masing sub sektor.

$$
\begin{aligned}
& \mathrm{F}=\frac{S b^{2}}{S w^{2}} \\
& S b^{2}=\frac{n_{1}\left(\overline{\mathrm{RU}_{1}}-\overline{\mathrm{RU}}\right)^{2}+n_{2}\left(\overline{\mathrm{RU}_{2}}-\overline{\mathrm{RU}}\right)^{2}+n_{3}\left(\overline{\mathrm{RU}_{3}}-\overline{\mathrm{RU}}\right)^{2}}{k-1} \\
& S w^{2}=\sum_{i j} \frac{\left(R U_{i j}-\overline{R U_{n}}\right)^{2}}{N-k} \\
& \text { Keterangan : } \\
& S b^{2}=\text { varian keputusan pendanaan antar } \\
& \text { kelompok sub sektor manufaktur } \\
& S w^{2}=\text { varian keputusan pendanaan dalam } \\
& \text { kelompok sub sektor manufaktur } \\
& \overline{R U}=\text { rata-rata rasio utang }(\text { SDTA, LDTA } \\
& \text { atau DTA) gabungan semua sub } \\
& \text { sektor manufaktur } \\
& \overline{\mathrm{RU}}_{n}=\text { rata-rata rasio utang }(\text { SDTA, LDTA } \\
& \text { atau DTA) masing-masing sub } \\
& \text { sektor manufaktur } \\
& R U_{i j}=\text { rata-rata rasio utang }((S D T A, L D T A \\
& \text { atau DTA) pada kelompok } j \text { dan } \\
& \text { observasi ke } i \\
& n_{n}=\text { banyaknya sampel pada kelompok } \\
& \text { masing-masing sub sektor manufaktur } \\
& \mathrm{N}=\text { Total banyaknya sampel } \\
& \mathrm{k}=\text { banyaknya kelompok/sub sektor }
\end{aligned}
$$

Model analisis multiple regression untuk menganalisis pengaruh variabel independen terhadap variabel dependen. Berikut merupakan model regresi berganda yang digunakan pada penelitian ini adalah:

$$
\begin{aligned}
& D T A_{i t}= \\
& \alpha_{1}+\beta_{11} S Z_{i t}+\beta_{12} P R O F_{i t}+\beta_{13} S A_{i t}+ \\
& \beta_{14} \mathrm{GRW}_{\mathrm{it}}+\beta_{15} \mathrm{RSK}_{\mathrm{it}}+\varepsilon \text {. }
\end{aligned}
$$

$S D T A_{i t}=$

$\alpha_{2}+\beta_{21} S Z_{i t}+\beta_{22} P R O F_{i t}+\beta_{23} S A_{i t}+$

$\beta_{24} \mathrm{GRW}_{\mathrm{it}}+\beta_{25} \mathrm{RSK}_{\mathrm{it}}+\varepsilon$

$$
\begin{aligned}
& \operatorname{LDT} A_{i t}= \\
& \alpha_{3}+\beta_{31} S Z_{i t}+\beta_{32} P_{R O F}+\beta_{33} S A_{i t}+ \\
& \beta_{34} \mathrm{GRW}_{\mathrm{it}}+\beta_{35} \mathrm{RSK}_{\mathrm{it}}+\varepsilon
\end{aligned}
$$

Keterangan :

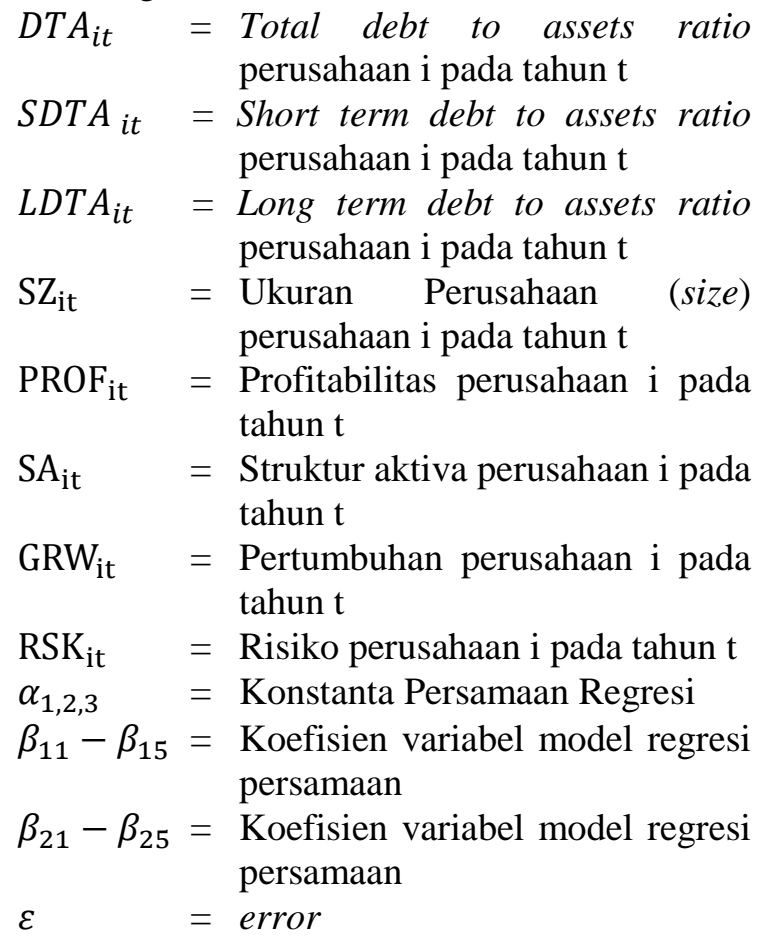

\section{HASIL DAN PEMBAHASAN}

\section{Deskripsi variabel}

Pada Tabel 1 menunjukkan deskripsi statistik data variabel independen maupun depenpen pada masing-masing sub sektor industri. Ratarata utang jangka pendek yang terbesar yaitu pada sub sektor aneka industri yaitu 39.80\%, rata-rata utang jangka panjang yang terbesar adalah sub sektor industri dasar kimia sebesar $16.33 \%$. Proporsi penggunaan utang pada semua sub sektor yang terbesar adalah utang jangka pendek. Consumer goods merupakan sub sektor dengan mean size profitabilitas dan risiko bisnis terbesar dibandingkan dengan sub sektor lainnya. 
Tabel 1: Deskripsi Data Statistik

\begin{tabular}{lcccccccc}
\hline \multicolumn{1}{c}{ Nilai } & Variabel & $\begin{array}{c}\text { Aneka } \\
\text { Industri }\end{array}$ & $\begin{array}{c}\text { Consumer } \\
\text { Goods }\end{array}$ & $\begin{array}{c}\text { Industri } \\
\text { Dasar } \\
\text { Kimia }\end{array}$ & Variabel & $\begin{array}{c}\text { Aneka } \\
\text { Industri }\end{array}$ & $\begin{array}{c}\text { Consumer } \\
\text { Goods }\end{array}$ & $\begin{array}{c}\text { Industri } \\
\text { Dasar } \\
\text { Kimia }\end{array}$ \\
\hline Minimum & & $10.33 \%$ & $5.06 \%$ & $2.76 \%$ & & $-9.29 \%$ & $-8.13 \%$ & $-0.99 \%$ \\
Maksimum & SDTA & $101.43 \%$ & $89.86 \%$ & $202.09 \%$ & PROF & $20.43 \%$ & $42.15 \%$ & $44.53 \%$ \\
Rata-rata & & $39.80 \%$ & $29.24 \%$ & $31.50 \%$ & & $5.25 \%$ & $12.04 \%$ & $9.54 \%$ \\
Minimum & & $0.71 \%$ & $1.55 \%$ & $0.14 \%$ & & 0.001 & 0.009 & 0.029 \\
Maksimum & LDTA & $54.90 \%$ & $71.30 \%$ & $112.02 \%$ & SA & 0.753 & 0.620 & 0.764 \\
Rata-rata & & $12.33 \%$ & $11.52 \%$ & $16.33 \%$ & & 0.356 & 0.293 & 0.400 \\
Minimum & & $12.43 \%$ & $9.43 \%$ & $7.39 \%$ & & $-60.75 \%$ & $-39.88 \%$ & $58.66 \%$ \\
Maksimum & \multirow{2}{*}{ DTA } & $108.98 \%$ & $94.81 \%$ & $208.69 \%$ & GRW & $-340.75 \%$ & $148.55 \%$ & $72.10 \%$ \\
Rata-rata & & $52.17 \%$ & $40.91 \%$ & $47.62 \%$ & & $13.56 \%$ & $13.54 \%$ & $9.32 \%$ \\
Minimum & & 10.970 & 11.300 & 11.735 & & -105.86 & -41.483 & -102.22 \\
Maksimum & SIZE & 18.683 & 17.78 & 16.704 & RSK & 778.96 & 2261.75 & 522.39 \\
Rata-rata & & 14.061 & 14.24 & 14.133 & & 18.05 & 28.217 & 12.40 \\
\hline Sira
\end{tabular}

Sumber: Data diolah

\section{Analiasis Hasil Penelitian}

Hasil uji ANOVA pada Tabel 2 menunjukkan nilai signifikansi dari penggunaan utang jangka pendek (SDTA) sebesar 0,002 dan total utang $(D T A)$ sebesar 0.006, hal ini berarti terdapat perbedaan yang signifikan nilai rata-rata total SDTA dan DTA antar ketiga sub sektor, yaitu sub sektor aneka industri, consumer goods dan industri dasar dan kimia. Rata-rata rasio utang jangka pendek terhadap total aset (SDTA), menunjukkan terdapat perbedaan yang signifikan antara sub sektor aneka industri dan consumer goods, dan juga antara sub sektor aneka industri dan industri dasar kimia, Sub sektor yang memiliki perbedaan yang signifikan rata-rata penggunaan total utang
(DTA), adalah antara sub sektor aneka industri dan consumer goods.

Hasil analisis regresi perusahaan aneka industri terlihat pada Tabel 3. Dari tabel tersebut dapat dilihat bahwa size dan risiko bisnis berpengaruh positif signifikan terhadap DTA dan LDTA, sedangkan profitabilitas dan struktur aktiva berpengaruh negatif signifikan terhadap DTA dan SDTA,

Tabel 4, menunjukkan hasil analisis regresi pada sub sektor consumer goods. Hasil analisis regresi sub sektor consumer goods menunjukan size berpengaruh positif signifikan terhadap SDTA, sedangkan profitabilitas berpengaruh negatif signifikan terhadap $L D T A$

Tabel 2: Hasil Analisis ANOVA

\begin{tabular}{|c|c|c|c|c|c|c|}
\hline \multirow{2}{*}{ Sub Sektor } & \multicolumn{6}{|c|}{ Var. Dependen } \\
\hline & DTA & & SDTA & & LDTA & \\
\hline Aneka Industri & $52.17 \%$ & & $39.80 \%$ & & $12.33 \%$ & \\
\hline Consumer Goods & $40.91 \%$ & & $29.24 \%$ & & $11.52 \%$ & \\
\hline Industri Dasar Kimia & $47.62 \%$ & & $31.50 \%$ & & $16.33 \%$ & \\
\hline F statistic & 5.282 & & 6.550 & & 2.733 & \\
\hline Sig & 0.005 & & 0.002 & & 0.067 & \\
\hline Multiple Comparison & $\begin{array}{c}\text { mean } \\
\text { difference }\end{array}$ & sig & $\begin{array}{c}\text { mean } \\
\text { difference }\end{array}$ & sig & $\begin{array}{c}\text { mean } \\
\text { difference }\end{array}$ & Sig \\
\hline Aneka Industri - Consumer Goods & 0.11259 & 0.003 & 0.1055735 & 0.002 & 0.008105 & 0.937 \\
\hline Consumer Goods - Industri Dasar Kimia & -0.067036 & 0.099 & -0.0225868 & 0.72 & -0.04807 & 0.081 \\
\hline Industri Dasar Kimia - Aneka Industri & -0.045562 & 0.347 & -0.0829867 & 0.015 & 0.039965 & 0.18 \\
\hline
\end{tabular}

Sumber: Data diolah 
Tabel 3: Hasil Analisis Pengaruh Karakteristik Perusahaan Terhadap Keputusan Pendanaan Pada Sub Sektor Aneka Industri

\begin{tabular}{lrcrrrrrrr}
\hline \multirow{2}{*}{$\begin{array}{l}\text { Var. } \\
\text { Independen }\end{array}$} & \multicolumn{9}{c}{ Var. Dependen } \\
\cline { 2 - 10 } & \multicolumn{3}{c}{ DTA } & \multicolumn{9}{c}{ SDTA } & \multicolumn{3}{c}{ LDTA } \\
\hline Koefisien & t-statistik & Sig T & Koefisien & t-statistik & Sig T & Koefisien & t-statistik & Sig T \\
\hline SIZE & 0.397 & 4.140 & 0.000 & .208 & 1.939 & 0.056 & 0.416 & 4.058 & 0.000 \\
PROF & -0.703 & -6.828 & 0.000 & -.530 & -4.631 & 0.000 & -0.154 & -1.422 & 0.159 \\
SA & -0.325 & -3.433 & 0.001 & -.315 & -2.992 & 0.004 & 0.031 & 0.303 & 0.763 \\
GRW & 0.160 & 1.795 & 0.077 & .132 & 1.325 & 0.189 & 0.137 & 1.422 & 0.159 \\
RSK & 0.229 & 2.524 & 0.014 & -.011 & -0.111 & 0.912 & 0.387 & 3.941 & 0.000 \\
R square & & 0.410 & & & 0.250 & & & 0.321 & \\
F-statistik & & 10.680 & & & 5.192 & & & 7.718 & \\
Sig F & & 0.000 & & & 0.000 & & 0.000 & \\
\hline Signyyyyyyyyyyy
\end{tabular}

Sumber: Data diolah

Tabel 4: Hasil Analisis Pengaruh Karakteristik Perusahaan

Terhadap Keputusan Pendanaan Pada Sub Sektor Consumer Goods

\begin{tabular}{|c|c|c|c|c|c|c|c|c|c|}
\hline \multirow{3}{*}{$\begin{array}{c}\text { Var. } \\
\text { Independen }\end{array}$} & \multicolumn{9}{|c|}{ Var. Dependen } \\
\hline & \multicolumn{3}{|c|}{ DTA } & \multicolumn{3}{|c|}{ SDTA } & \multicolumn{3}{|c|}{ LDTA } \\
\hline & Koefisien & t-statistik & Sig T & Koefisien & t-statistik & $\operatorname{Sig} T$ & Koefisien & t-statistik & Sig T \\
\hline SIZE & 0.164 & 1.433 & 0.156 & 0.390 & 3.550 & 0.001 & 0.020 & 0.186 & 0.853 \\
\hline PROF & -0.219 & -1.934 & 0.057 & 0.030 & 0.275 & 0.784 & -0.339 & -3.141 & 0.002 \\
\hline SA & 0.137 & 1.256 & 0.213 & 0.210 & 1.975 & 0.052 & 0.183 & 1.745 & 0.085 \\
\hline GRW & 0.112 & 1.046 & 0.299 & 0.010 & 0.100 & 0.921 & 0.141 & 1.377 & 0.172 \\
\hline RSK & -0.101 & -0.928 & 0.356 & -0.082 & -0.778 & 0.439 & -0.100 & -0.961 & 0.340 \\
\hline R-squared & & 0.094 & & & 0.190 & & & 0.183 & \\
\hline F-statistik & & 1.685 & & & 3.661 & & & 3.582 & \\
\hline Sig F & & 0.148 & & & 0.005 & & & 0.006 & \\
\hline
\end{tabular}

Sumber: Data diolah

Pada Tabel 5 merupakan hasil analisis regresi pada sub sektor industri dasar dan kimia. Hasil analisis regresi menunjukkan bahwa size berpengaruh positif signifikan terhadap variabel DTA dan LDTA. Profitabilitas berpengaruh negatif signifikan terhadap ketiga ukuran keputusan pendanaan, sedangkan truktur aktiva berpengaruh negatif signifikan terhadap SDTA dan berpengaruh positif signifikan terhadap LDTA. Growth berpengaruh positif signifikan terhadap SDTA.

Tabel 5: Hasil Analisis Pengaruh Karakteristik Perusahaan Terhadap

Keputusan Pendanaan Pada Sub Sektor Industri Dasar dan Kimia

\begin{tabular}{|c|c|c|c|c|c|c|c|c|c|}
\hline \multirow{3}{*}{$\begin{array}{c}\text { Var. } \\
\text { Independen }\end{array}$} & \multicolumn{9}{|c|}{ Var. Dependen } \\
\hline & \multicolumn{3}{|c|}{ DTA } & \multicolumn{3}{|c|}{ SDTA } & \multicolumn{3}{|c|}{ LDTA } \\
\hline & Koefisien & t-statistik & Sig T & Koefisien & t-statistik & Sig T & Koefisien & t-statistik & Sig T \\
\hline SIZE & 0.327 & 3.412 & 0.001 & 0.135 & 1.353 & 0.179 & 0.275 & 3.087 & 0.003 \\
\hline PROF & -0.487 & -5.341 & 0.000 & -0.397 & 4.222 & 0.000 & -0.203 & 2.430 & 0.017 \\
\hline SA & 0.107 & 1.170 & 0.245 & -0.272 & 2.879 & 0.005 & 0.459 & 5.337 & 0.000 \\
\hline GRW & 0.080 & 0.927 & 0.356 & 0.217 & 2.426 & 0.017 & -0.036 & 0.448 & 0.655 \\
\hline RSK & 0.030 & 0.346 & 0.730 & $-4.848 \times 10^{-4}$ & -0.005 & 0.996 & 0.092 & 1.122 & 0.265 \\
\hline $\mathrm{R}$ square & \multicolumn{3}{|c|}{0.294} & \multicolumn{3}{|c|}{0.243} & \multicolumn{3}{|c|}{0.399} \\
\hline F-statistik & \multicolumn{3}{|c|}{8.066} & \multicolumn{3}{|c|}{6.213} & \multicolumn{3}{|c|}{12.463} \\
\hline Sig F & \multicolumn{3}{|c|}{0.000} & \multicolumn{3}{|c|}{0.000} & \multicolumn{3}{|c|}{0.000} \\
\hline
\end{tabular}

Sumber : Data diolah 


\section{Pembahasan}

Berdasarkan hasil analisis yang dilakukan, terdapat perbedaan pengaruh karakteristik industri terhadap keputusan pendanaan pada masing-masing sub sektor. Keputusan pendanaan jangka pendek pada sub sektor aneka industri dipengaruhi oleh profitabilitas dan struktur aset, pada sub sektor consumer goods dipengaruhi oleh size dan pada sub sektor industri dasar kimia dipengaruhi oleh profitabilitas, struktur aset dan growth. Hal ini dikarenakan perusahaan pada sub sektor aneka industri dan industri dasar kimia dengan profitabilitas yang semakin tinggi, maka perusahaan akan memiliki cadangan dana internal berupa laba ditahan yang semakin besar. Laba ditahan tersebut dapat digunakan perusahaan untuk membiayai investasi, sehingga penggunaan dana eksternal berupa utang jangka pendek menjadi berkurang. Profitabilitas berpengaruh negatif terhadap keputusan pendanaan jangka pendek ini sesuai dengan penelitian yang Abor (2007) dan Buferna, et al (2005).

Keputusan pendanaan jangka pendek pada sub sektor aneka industri dan industri dasar kimia dipengaruhi oleh struktur aset, kedua sub sektor ini merupakan industri dengan aset tetap yang tinggi dan lebih mengandalkan utang jangka panjang untuk membiayai aset tetapnya, sehingga kebutuhan akan utang jangka pendek akan menurun seiring dengan bertambahnya aset tetap perusahaan. Hasil penelitian ini sesuai dengan penelitian Omran dan Pointon (2009) dan Mouamer (2011). Keputusan Pendanaan jangka pendek pada sub sektor industri dasar kimia selain dipengaruhi oleh profitabilitas dan struktur aset, juga dipengaruhi oleh growth. Hal tersebut dikarenakan kreditor menilai pertumbuhan penjualan pada sub sektor ini sebagai proyeksi atas kemampuan perusahaan untuk melunasi utangnya. Perusahaan dengan pertumbuhan penjualan yang semakin tinggi akan membutuhkan pendanaan yang lebih besar dan kreditor juga mempunyai kepercayaan lebih tinggi untuk memberikan pinjaman kepada perusahaan dengan tingkat pertumbuhan yang meningkat. Pengaruh positif growth terhadap keputusan pendanaan jangka pendek sesuai dengan penelitian Abor (2007) dan Buferna, et al (2005).

Tabel 5: Hasil Pengaruh Karakteristik Perusahaan Terhadap Keputusan Pendanaan

\begin{tabular}{clcccc}
\hline \multirow{2}{*}{ Sub Sektor } & \multirow{2}{*}{ Var Independen } & \multirow{2}{*}{ Hipotesis } & \multicolumn{4}{c}{ Var Dependen } \\
\cline { 4 - 6 } & SIZE & & SDTA & LDTA & DTA \\
\hline \multirow{5}{*}{ Aneka Industri } & PROF & + & $(+)$ & $(+)^{*}$ & $(+)^{*}$ \\
& SA & - & $(-)^{*}$ & $(-)$ & $(-)^{*}$ \\
& GRW & + & $(-)^{*}$ & $(+)$ & $(-)^{*}$ \\
& RSK & + & $(+)$ & $(+)$ & $(+)$ \\
& SIZE & - & $(-)$ & $(+)^{*}$ & $(+)^{*}$ \\
& PROF & + & $(+)^{*}$ & $(+)$ & $(+)$ \\
Consumer Goods & SA & - & $(+)$ & $(-)^{*}$ & $(-)$ \\
& GRW & + & $(+)$ & $(+)$ & $(+)$ \\
& RSK & + & $(+)$ & $(+)$ & $(+)$ \\
& SIZE & - & $(-)$ & $(-)$ & $(-)$ \\
& PROF & + & $(+)$ & $(+)^{*}$ & $(+)^{*}$ \\
Industri Dasar dan Kimia & SA & - & $(-)^{*}$ & $(-)^{*}$ & $(-)^{*}$ \\
& GRW & + & $(-)^{*}$ & $(+)^{*}$ & $(+)$ \\
NB: * = signifikan pada 5\% & RSK & + & $(+)^{*}$ & $(-)$ & $(+)$ \\
& & - & $(+)$ & $(+)$ & $(+)$ \\
\hline
\end{tabular}


Keputusan pendanaan jangka pendek pada sub sektor consumer goods hanya dipengaruhi oleh size, karena sub sektor ini merupakan industri dengan keadaan yang relatif stabil dibandingan dengan sub sektor lainnya. Persaingan untuk memasuki sub sektor ini juga lebih ketat dibandingkan dengan sub sektor lainnya. Perusahaan besar pada sub sektor ini lebih mendominasi dan dipercaya pasar, sehingga perusahaan kecil akan kesulitan untuk masuk dan berkembang. Oleh karena itulah kreditor akan lebih memilih untuk memberikan pinjaman kepada perusahaan besar dibandingkan dengan perusahaan kecil. Size berpengaruh positif terhadap keputusan pendanaan ini sesuai dengan penelitian yang dilakukan Abor (2007) dan Buferna, et al (2005).

Keputusan pendanaan jangka panjang pada masing-masing sub sektor industri manufaktur dipengaruhi oleh variabel yang berbeda. Keputusan pendanaan jangka panjang pada sub sektor aneka industri dipengaruhi oleh size dan risiko bisnis, pada sub sektor consumer goods hanya dipengaruhi oleh profitabilitas, sedangkan keputusan pendanaan jangka panjang pada sub sektor industri dasar kimia dipengaruhi oleh size, profitabilitas dan struktur aset. Hal ini karena perusahaan pada sub sektor aneka industri merupakan industri yang membutuhkan mesin-mesin yang canggih dalam produksinya. Perusahaan pada sub sektor aneka industri dengan size yang semakin besar akan membutuhkan pendanaan jangka panjang yang semakin meningkat. Hal itu dikarenakan perusahaan dengan size yang besar mempunyai penjualan yang besar, sehingga perusahaan membutuhkan pendanaan yang besar untuk menambah kapasitas produksi. Kekurangan pendanaan ini diperoleh perusahaan dengan mengajukan pinjaman kreditor. Kreditor dalam hal ini akan lebih memilih untuk memberikan pinjaman kepada perusahaan dengan penjualan yang besar dibandingkan dengan perusahaan dengan tingkat penjualan yang kecil. Pengaruh positif size terhadap keputusan pendanaan jangka panjang sesuai dengan penelitian Sheikh and Wang (2012) dan Abor (2007)

Keputusan pendanaan jangka panjang sub sektor aneka industri juga dipengaruhi risiko bisnis yang diproksikan dengan $D O L$. Perusahaan pada sub sektor aneka industri merupakan perusahaan padat modal, yaitu perusahaan yang menggunakan tenaga kerja sedikit dan aktiva tetap yang banyak serta canggih. Perusahaan padat modal mempunyai $D O L$ yang tinggi dan sensitif terhadap perubahan penjualan. Apabila terjadi penurunan penjualan, maka perusahaan tersebut akan mengalami penurunan EBIT yang lebih besar dibandingkan perusahaan dengan $D O L$ yang lebih rendah. Penurunan EBIT akan berdampak pada penurunan laba ditahan, sehingga kebutuhan dana akan dipenuhi dengan utang. Meskipun resiko bisnis perusahaan besar, perusahaan tetap berani menggunakan utang dikarenakan selama periode penelitian menunjukkan kondisi perekonomian Indonesia yang membaik, dilihat dari pertumbuhan ekonomi yang terus mengalami kenaikan tiap tahunnya dari 4,6\% pada 2009 menjadi 6,5\% pada 2011 (BPS, 2014). Risiko bisnis berpengaruh positif terhadap keputusan pendanaan sesuai dengan hasil penelitian Omran dan Pointon (2009) dan Huang dan Song.

Keputusan pendanaan jangka panjang pada sub sektor industri dasar kimia dipengaruhi oleh size struktur aset dan profitabilitas. Hal ini dikarenakan perusahaan besar dengan penjualan yang besar pada sub sektor ini akan mendapat kepercayaan yang lebih tinggi dari kreditor, sehingga perusahaan akan lebih mudah memperoleh tambahan pinjaman jangka panjang. Utang jangka panjang tersebut digunakan untuk membiayai investasi pada aktiva tetap, sehingga ketika struktur aktiva meningkat, utang jangka panjang juga meningkat. Hasil size berpengaruh positif terhadap keputusan pendanaan jangka panjang sesuai dengan penelitian Buferna, et al (2005) dan Abor (2007). Struktur aktiva berpengauh positif terhadap keputusan pendanaan jangka panjang sesuai dengan Mouamer (2011) dan Chen (2003). Pada sub sektor industri dasar dan kimia, keputusan pendanaan jangka panjang juga dipengaruhi oleh profitabilitas, sama halnya dengan keputusan pendanaan jangka panjang pada sub sektor consumer goods. Perusahaan dengan kemampuan menghasilkan laba yang meningkat justru akan mengurangi penggunaan utang jangka panjangnya. Hal tersebut dikarenakan perusahaan dengan profitabilitas yang tinggi mempunyai kemampuan menghasilkan laba yang semakin tinggi, sehingga perusahaan memiliki cadangan dana internal yang juga semakin besar. Dana internal 
atau laba ditahan tersebut digunakan untuk membiayai investasi perusahaan, sehingga kebutuhan perusahaan akan pendanaan eksternal perusahaan akan semakin berkurang. Hasil ini sesuai dengan penelitian yang dilakukan Chen (2003) dan penelitian Sheikh dan Wang (2012).

Keputusan pendanaan total pada masing-masing sub sektor dipengaruhi oleh variabel-variabel yang berbeda, yaitu sub sektor aneka industri dipengaruhi oleh size, profitabilitas, struktur aset dan DOL, namun keputusan pendanaan total sub sektor consumer goods, tidak dipengaruhi oleh variabel yang diteliti, sedangkan total pada sub sektor industri dasar kimia dipengaruhi oleh size dan profitabilitas. Pengaruh karakteristik industri tersebut terhadap total utang sub sektor aneka industri, dikarenakan variabel-variabel tersebut terbukti berpengaruh terhadap keputusan pendanaan jangka panjang dan keputusan pendanaan jangka pendek perusahaan. Hal tersebut menunjukkan bahwa variabel yang berpengaruh terhadap keputusan pendanaan jangka pendek ataupun keputusan pendanaan jangka panjang, berpengaruh juga terhadap keputusan pendanaan total perusahaan sub sektor aneka industri.

Keputusan pendanaan total pada sub sektor industri dasar kimia dipengaruhi oleh size dan profitabilitas. Hal itu karena di antara semua variabel karakteristik industri, size dan profitabilitas adalah variabel mempunyai pengaruh yang konsisten dan signifikan, baik terhadap keputusan pendanaan jangka panjang dan keputusan pendanaan jangka pendek, sedangkan variabel yang lain mempunyai pengaruh yang tidak konsisten.

\section{SIMPULAN}

Berdasarkan hasil analisis dan pembahasan, penelitian ini menghasilkan kesimpulan sebagai berikut: 1) Total debt to total asset dan short term debt to total asset memiliki perbedaan yang signifikan antar sub sektor aneka industri, consumer goods dan industri dasar dan kimia. 2) Keputusan pendanaan jangka pendek sub sektor aneka industri dipengaruhi oleh profitabilitas dan struktur aktiva, pada sub sektor consumer goods dipengaruhi oleh size, sedangkan sub sektor industri dasar kimia dipengaruhi oleh profitabilitas, strutur aktiva dan growth. 3) Keputusan pendanaan jangka panjang pada sub sektor aneka industri dipengaruhi oleh size dan risiko bisnis, pada sub sektor consumer goods dipengaruhi profitabilitas, sedangkan pada sub sektor industri dasar kimia dipengaruhi oleh size profitabilitas dan struktur aktiva. 4) Total debt to total asset sub sektor aneka industri dipengaruhi oleh size profitabilitas, struktur aktiva dan risiko bisnis, sedangkan pada sub sektor industri dasar kimia dipengaruhi oleh sizedan profitabilitas.

\section{DAFTAR REFERENSI}

Abor, Josua. 2007. Industry Classification and The Capital Structure of Ghanaian SMEs. Studies in Economics and Finance, 24: 207-219.

2007. Corporate Governance and Financing Decisions of Ghanaian Listed Firms. Corporate Governance, 7: $83-92$

Bokpin, G.A., and Arko, A.C., 2009. Ownership Structure, Corporate Governance and Capital Structure Decisions of Firms: Empirical Evidence from Ghana. Studies in Economics and Finance, 26: 246-256.

Brealey, R., S. Myers, and A. Marcus, 2001. Fundamentals of Corporate Finance. Third Edition. New York: Mc Graw Hill International Edition.

Brigham, Eugene F dan Joel F. Houston. 2001. Manajemen Keuangan. Jakarta: Penerbit Erlangga

Buferna, F., Bangassa, K., and Hodgkinsn, L. 2005. Determinants of Capital Structure Evidence from Libya. Research Paper Series, University of Liverpool.

Chen, Jean J. 2003. Determinants of Capital Structure of Chinese-listed Companies. Journal of Business Research, 57: 1341- 1351 .

Eriotis, N., Vasiliou, D., and VentouraNeokosmidi, Z. 2007. How Firm Characteristics Affect Capital Structure: An Empirical Study. Managerial Finance, Vol. 33: 321 - 331. 
Haley, C.W. and Lawrence D. Schall. 1979. The Theory of Financial Decisions. Second Edition. Mc Graw Hill International Edition.

Indonesian Stock Exchange. 2012. www.idx.co.id IDX Fact Book 2012

Indrajaya, G., Herlina., dan Setiadi, R., 2011. Pengaruh Struktur Aktiva, Ukuran Perusahaan, Tingkat Pertumbuhan, Profitabilitas dan Risiko Bisnis Terhadap Struktur Modal. Akurat Jurnal Ilmiah Akuntansi, 6.

Mouamer, Faris M. Abu. 2011. The Determinants of Capital Structure of Palestine-listed Companies. Journal of Risk Finance, 12: 226-241.

Omran, M.M. and Pointon, J. 2009. Capital Structure and Firm Characteristics: An Empirical Analysis from Egypt. Review of Accounting and Finance. 8: 454474.
Ozkan, A. 2001. "Determinant of Capital Structure and Adjusment to Long Run Target: Evidence from UK Company Panel Data". Journal of Business Finance and Accounting, 28: 175-198.

Suad, Husnan. 2001. Dasar-Dasar Teori Portofolio dan Analisis Sekuritas. Yogyakarta: Penerbit dan Percetakan AMP YKPYN.

Sudana, I Made. 2009. Manajemen Keuangan Teori dan Praktik. Surabaya: Airlangga University Press.

Riyanto, Bambang 2001. Dasar-Dasar Pembelanjaan Perusahaan, Edisi Keempat, Cetakan Ketujuh, Yogyakarta: BPFE

Wald, John K. 1999. How Firm Characteristics Affect Capital Structure: An International Comparison. The Journal of Financial Research, 22 (2): 161-187. 